\title{
High level discourse and low level readers: an unlikely marriage
}

\section{Ray Cooke}

\section{(2) OpenEdition}

1 Journals

Electronic version

URL: https://journals.openedition.org/asp/3891

DOI: 10.4000/asp.3891

ISSN: 2108-6354

\section{Publisher}

Groupe d'étude et de recherche en anglais de spécialité

\section{Printed version}

Date of publication: 1 December 1995

Number of pages: $217-230$

ISSN: 1246-8185

\section{Electronic reference}

Ray Cooke, "High level discourse and low level readers: an unlikely marriage", ASp [Online], 7-10 | 1995,

Online since 28 October 2013, connection on 21 September 2021. URL: http://

journals.openedition.org/asp/3891 ; DOI: https://doi.org/10.4000/asp.3891

This text was automatically generated on 21 September 2021.

Tous droits réservés 


\title{
High level discourse and low level readers: an unlikely marriage
}

\author{
Ray Cooke
}

1 Were it not for the fact that some categories of learners are required by their employer to become familiar with technical English, ${ }^{1}$ there are some people who would never get near a specialised text. On the other hand, there are native speakers who would also never get near one either. In other words, despite an otherwise nonexistent need to use English, some professionals, be they of whatever level of competence, are required to master, or at least be operationally familiar with, very specific genres and genre skills which go well beyond the realm of average native-speaker competence. ${ }^{2}$

2 Such is the case with the group I describe here. Françoise, Bernadette, Sylvie and the two Martines are laboratory technicians who work for a well-known pharmaceutical company. All have studied English in the past (two to a fairly limited level and only one with the classic seven-year profile), some are quite older than the others (these tend intrinsically to be the less competent ones), all but the eldest have school-age children and therefore obligations not conducive to ideal language learning, and all have received some form of encouragement-cum-pressure to improve their reading skills in English so as to be able to transmit technical and/or procedural information to those working with them. None of them is of executive status. When I naively asked the director of further education whether it might not be more immediately productive to ask the lab directors with their long-acquired day-to-day hands-on experience of technical texts to transfer the information themselves, the laconic reply said all. "The different hierarchies don't tend to mix like that". We have, then, all the ingredients for a pretty tough time:

3 - Low level readers: intra-group heterogeneity, intra- and extra-muros obstacles, little or no help from above, education to 'bac' level (except one);

4 - Facing high level discourse: conceptual subject difficulties, text organisational difficulties.

5 Why conceptual subject difficulties? An old ESP adage has it that if you take the linguistic knowledge of the teacher and couple it with the subject knowledge of the learner, then 
the twain shall meet, and in my experience, this is largely true. Not with my lab technicians, however. Our first class contact showed how a new approach would have to be developed. How it would be necessary to arrive at understanding by routes I had not hitherto travelled. And as for text organisational difficulties, my learners were quick to inform me (although it was clear to me anyway) that until then, technical English looked like gibberish to them, certainly not like the English with which they had had more or less fleeting contact until then. In a much discussed paper at the 3rd European Symposium on LSP, Kurt Opitz stated his conviction that

[...] LSP - contrary to what we tend to assume in using the term - is not the failsafe, objective lingua franca within given subject areas which assures instant communication. It is a medium, but it is the message as well.

On learning, in our first session together, that some scientists seem to pride themselves on their use of the abstruse and pataphysical, to use Opitz's terms, my learners were amused but in no way reassured. And no wonder. The ground that they were going to have to make up in the 20 hours that their company had allotted them (and therefore me), in comparison to younger, fresher, sharper learners, was indeed daunting. What Opitz (1985: 101) refers to as "string style" and Monique Mémet (1994: 94) as "l'empilage des mots et des expressions idiomatiques" represents potentially an insurmountable syntactic obstacle for such learners. Clearly, certain acquisitions which may largely be taken for granted in a higher education setting were not to be considered so here.

7 If we are to believe Krashen and the affective filter theory, then our lab. technicians had to increase their true "uncoerced" motivation and curiosity to be able to progress in technical English. "Uncoerced" because these ladies had both carrot and stick to drive them forward. What was fundamental in my mind was that they should learn how to like to learn. But how? Telling someone something is good for them is not enough. How do you show someone how to understand what is apparently quasi-gibberish?

The literature is of course full of good advice: go through an ESP reading manual, cover to cover; or do a general English course, followed by the ESP ; or go into the deep end by translating the authentic, because with time, they'll start to 'get the message'. None of these would do. The first presupposes existing knowledge which these people didn't have: moreover, more boring than this would be hard to find. The second would be akin to learning the piano the old way - "you'll actually touch the piano next year, my boy". Do the third and you'll be like the banker frustrated by his constantly overdrawn client whose language balance is forever negative, since it is unrealistic to expect him to know how to save. It was therefore necessary to negotiate with the learners the choice of methods and materials. Dick Allwright (1991:11) has summarised this nicely:

The whole business of the management of language learning is far too complex to be satisfactorily catered for by a pre-packaged set of decisions embodied in teaching materials. This is obvious if we recognise that, while teaching materials may embody decisions, they cannot themselves undertake the action and the review phases of the management process.

Arrived our first lesson. This was not the first time I had seen them, however, since they had already done a short placement test, itself administered with all due precaution not to reinforce in them the impression of knowing precious little. All instructions for the test had been given in French, and all evaluation and comment with each learner likewise. This seems self-evident, otherwise we could not have spoken to each other. Yet it is remarkable how much pressure there is in the language teaching profession to use 
English exclusively, presumably till you're blue in the face. Michael Swan (1985) makes this point about the omnipotent British version of the communicative approach:

Communicative methodology stresses the English-only approach to presentation and practice that is such a prominent feature of the British EFL tradition. (Perhaps because this has made it possible for us to teach English all over the world without the disagreeable necessity of having to learn other languages?). (1985: 85)

Even closer to our present preoccupation, written comprehension in ESP, is a remark made by Arlette Dechet (1993) at this conference in 1992.

Nous devons rendre nos étudiants opérationnels au plus vite. Pourquoi leur faire perdre un temps précieux à trouver une explication en anglais qui risque d'être approximative alors que la traduction les oblige à plus de précision. Le but de ce travail n'est pas d'acquérir un maximum de vocabulaire et de structures de communication, mais de comprendre un texte pour pouvoir mieux tirer profit d'une machine, d'un logiciel ou d'un langage informatique. Soyons rapide et efficace. (1992: 149)

11 On a more general level, any pedagogic methodology serves as reference for other activity to be contrasted with it. In that sense, temporarily out-of-favour devices such as translation, dictation, substitution and so on need not be considered as necessarily undesirable, providing that through them, curiosity about the language can be triggered and motivation sustained. Could there be a situation where this is truer than with our low-level readers? To shut oneself into an ideology can only deprive the latter of the fullest possible range of high surrender learning activities. For Eddie Williams (1983, in Swan 1985: 85) it is paradoxical that

the use of authentic text with learners often has an effect opposite to that intended ; instead of helping the learner to read for the meaning of the message, an authentic text at too difficult a level of language forces the reader to focus upon the code. and, I would add, not on comprehension.

While it is understandable, on the one hand, to protect learners from the too difficult (whatever the criteria of difficulty are), it is, on the other, only fair not to pull the wool over their eyes. For my learners, at least, it was clear from the start that they would be expected by their superiors to be the vector of comprehension for a wide variety of textual genres, from technical manuals and lists of European directives and requirements, to research articles. True, I was able to make a pre-selection of documents from the mass I was handed prior to the course in order to compile a corpus, and to decide in which order they might be studied; but to slip difficult material to the bottom of the pile and probably never get to it would have been dishonest and without respect for the wishes of the learners whose need to be able to read was pressing. The problem had to be approached head-on.

14 A first glance at the article entitled "An approach to reduce the number of skin samples in testing the transdermal permeation of drugs" (Langguth et al. 1986) reveals how daunting the prospect seems of setting up the conditions for these learners to understand the information it contains. However, the point is that this text, and any like it, will contain a multiplicity of data, not all of which the reader necessarily requires to know. A considerable hurdle to overcome is to persuade anyone who does not have a research background and, therefore, the acquired skill of seeking particular information, that some of the text can be left aside. In a recent article in Reading Research Quarterly Symons and Pressley (1993) discuss the way in which prior knowledge affects text search success 
and extraction of information. They describe how, in the American National Assessment of Educational Progress, even though 96\% of the adults in the sample surveyed could locate a single piece of information in a newspaper article, only $37 \%$ could locate information when required to match three question features with three elements in the article, while $63 \%$ of the participants had attained a postsecondary degree. And the sample Anglophone population was reading in English! The authors show how prior knowledge either affects category selection by directing attention to appropriate sections of text (Anderson and Pearson, 1984), facilitates information extraction by mediating judgements of importance in light of the search goal (Anderson, 1984) or reduces working memory demands (Fincher-Kiefer 1988). Therefore, it is clearly a factor to be exploited to the full.

A device I have found simple and meaningful for all learners embarking on a reading course is to ask them what they do once they get the daily paper in their hands. Some say they start reading without giving the matter further thought; others say they read the titles on the front page, while others again will meekly admit to turning straight to the sports page. In other words, we may focus more or less innately in our own language, so why should we deprive ourselves of this useful tool in a foreign language with its host of unfamiliar words? The knowledge thus acquired is not only of a textual but also of a topographic nature, all of which contributes to allowing the reader to establish what Baten and Cornu (1985) have termed "mappings".

16 Another insight into the help we can provide low-level learners is offered by Wilga Rivers (1994). In describing the parallel distributed processing (PDP) approach to thought and memory, she lays the foundations for what some teachers may feel is right without knowing why. PDP theory has it that knowledge forms networks with a myriad of interconnected nodes. Since the nodes are probably conceptual, they are not languagespecific, so the concepts that we apprehend in our own language may have their mirrorimage in another. If memory is viewed in this way, words may be retrieved if they are initially made to be accessible. Accessibility can be encouraged if learners are constantly given the opportunity to reactivate their own networks through learner-centred activities, in which they collect their own personal vocabulary and grammar networks organised according to their own perceptions. Points of language can be recycled in this way, and will probably be learnt better for it. The term "recycling" describes this adequately, but more appropriate is Michel Perrin's term "spiralling" since it also implies an upward movement of construction. Seen in these terms, the learning of grammatical and structural rules is not an end in itself but more a vehicle for clarifying comprehension and consolidating the memory networks. Every opportunity should, therefore, be seized on to establish this body of knowledge as and when it occurs through what Robert O'Neill (1982) calls "creative accidents". The implications for our low-level learners are indeed great, because we have ruled out the traditional linear approach to learning, for reasons we discussed earlier. Therefore, they had to learn "on the job", with all the rough edges that that supposes. Michel Perrin (1990) reminds us that

Mastering the art of meaningful digression accounts, perhaps, for the most specific

aspect of our role as language teachers in a specific professional environment.

and it is this spirit which is the overriding concern in what my learners and I did together.

As already stated, the corpus for our lessons came exclusively from the learners. I asked them to give me reading material from their labs that they either had had to deal with in 
the past or would have to some time in the future. They gave me a mass of material from which, for reasons of the frequency with which they would meet such texts, I selected: chose the one which seemed relatively the most interesting, the one concerning transdermal permeation of ointments. "Relatively", because this is pretty boring stuff all in all. The point is, though, that it doesn't matter where you start, providing it is with some meaningful focusing on the matter in hand. Hutchinson and Waters (1987: 111) list five distinct benefits from focusing. Focusing provides the starting point to a phase of work, yet there can be no nicely timed endpoint to it. The learning process for these learners (and why not for all for that matter?) could be seen as a self-nurturing one, since their queries, which they must be encouraged to air despite their low level of knowledge and its corollary, a modicum of timidity, will trigger opportunities for learning new grammar and structures which would otherwise have had little applied meaning in a linear programmed approach. In this respect, the summary on glyceryl trinitrate (it could be one on the price of eggs, so little does it matter!) offers a wealth of opportunity for learning, providing the teacher grasps each occasion to generate knowledge of the language that could reasonably be taken for granted or quickly diagnosed and dealt with in a group of high-level language-domain learners such as pre-doctoral students. the learners as to how this information is to be stored. Nothing must be lost, so many notes must be taken, and time for this notetaking set aside. After all, these people are constructing the language largely for the first time. Perhaps I was expecting too much of my five "guinea pigs" when we started our course; being accustomed to working with students a) of a higher level in general, and b) who take notes day in day out, I did not initially notice that certain information was being lost, forgotten, or more to the point, not assimilated at all. So I made them think about the types of information they were recording. A simple structure was needed to enable each learner to record information if she felt it necessary to do so. We decided on the following rule of thumb categories:

1. Vocabulary: Technical - General

2. "Mots-Outils"

3. Formation of words: Verbs - Adjectives - Nouns - Adverbs

4. Rules explaining word order

5. Tenses : what and why?

6. Mathematical expressions/usages

This list may seem reductionist, but must be so for learners at this level to apprehend and classify their acquisitions. Moreover, there can be no definitively correct place for every piece of information. For example, if a learner feels that a gerund should be classified in the 'Verb' subsection of section 3, then so be it, even if it could arguably go in section 5 . The point here is that perception of stored items must be personal. This elaborate and sometimes fastidious notetaking (let's be honest) has been a constant feature of the work we have done together over the past two years, yet it meets the learners' partly companydriven, partly personal wants. Indeed, we are now starting our third 20-hour course; the 
second and third were requested by the learners who presumably would not have wished to continue if this hard graft had not been paying dividends.

In addition, the learners complement their notes with a cross-referencing system. Since the lines of each text in the corpus are numbered, it is possible to compare and record frequently occurring items and how they are used. For example, textual signposts such as "however" and "thus" no longer pose any problems of comprehension. Moreover, infrequent ones such as "so as + infinitive" tend now to be recognised as playing the role of signpost, even if their meaning may still not be clear. The point is that these learners have to be weaned from their state of dependence on external sources of reference such as dictionaries, manuals and people more knowledgeable than they are, and be made aware that they can still learn to be autonomous at this relatively late stage in their lives, providing they themselves construct the tools with which to learn. The teacher's role here is fundamental since he or she must adopt a reassuring manner, akin to a doctor's bedside handholding. Confidence is difficult to build, easy to destroy.

It is in this sense that much of what is rightly considered as efficient focusing activities (Hutchinson and Waters 1987: 106-27), "activity organisers" or "input enhancers" (to use some of the current terms used to describe what I understand to be one and the same thing), are not relevant with such low-level learners. Whereas pedagogic comprehension aids of a diagrammatic or visual nature are both useful and enjoyable for the vast majority of learners required to understand technical discourse, they may prove disconcerting with low level learners. What happens, for instance, if the diagrammatic aid is as difficult to understand as the text it is supposed to focus on? True, appropriate diagrammatic aids could be designed, but this misses the point... which is that many texts are just bland diagram-less blocks of words. The real problem lies upstream: to teach learners a) to use their prior knowledge ; b) to sort out the words ; and c) to have confidence in their own judgement in a domain where incorrect understanding could have serious consequences (Nyman 1994 : 779).

As mentioned above, our initial corpus contained eight items of which five were of the same text type or genres. To speak of genres to my learners would, I imagine, (since I didn't try to) have been to sow seed on stony ground. But to speak of what texts are trying to do for the reader seemed pertinent to them. Moreover, a cursory view of all eight was enough for them to realise that style can vary. Text type awareness was something which we would return to constantly during our lessons, since it was to provide the cohesive context for explaining the why and wherefore of discoveries such as the flourish of modals in the discussion of the research article, that of imperatives in the sets of operating instructions, and the abundance of passive forms throughout the corpus. ${ }^{3}$ To my mind, almost every discovery about the language needed to be accompanied by an upstream understanding of why it was being used, so that the learners could not only say " $I$ know ' $X$ ' is used in case ' $Y$ ', but also " $X$ ' is used in case ' $Y$ ' because of ' $Z$ '". Two examples:

A:"I know that I am likely to see many imperatives at the beginning of sentences in operating instructions because in this context, English requires the main verbal notion at the head of the sentence.

B: I can recognise passive forms. They normally come at the end of the clause and are commonly used to describe fixed or standard procedures.

Therefore, in the search for information, it was essential for the learners to understand why they had to read globally before specifically, to take careful notes of any discovery 
whatsoever, even if this meant that only a small amount of text was dealt with in a given lesson.

Ineluctably, there came the moment of starting in on the text. Systematically, I ask the learners to "sense group" every portion of every text we read together. Sense grouping is the logical grouping together, according to one's own perception, of the words in a sentence; e.g., /Cats chase mice/and mice chase spiders/. If this is not done with such learners, and with more experienced ones too, they can never begin to see the wood for the trees; particularly since much grammatical and structural upstream knowledge about the language derives from this step. When this concept has been understood and practised, it then becomes clear that on average a sense group contains between three and six words; sometimes two, very rarely seven or more, because in all likelihood, a learner who perceives seven or eight is probably not noticing a subdivision somewhere. My ladies were able to make considerable discoveries without my intervention, just by comparing systematically the points at which they felt they should insert their sense group dividers. Moreover, this technique is diagnostic, in that it enables the teacher to see where and why comprehension may not be taking place. Sentences ' $F$ ' and ' $G$ ' in the glyceryl trinitrate text are cases in point, both giving problems but for different reasons: sentence ' $F$ ' will pose problems because of the inability to recognise "With the aim to + gerund", and possibly because of the distance between subject and verb. Sentence G will pose problems through its sheer weight and, therefore, a gradual dilution of comprehension as the low-level reader moves through it. So it is essential that sense grouping precede any other work on the text per se with these learners. To begin with, a text can be prepared by the teacher with some of the divisions already indicated, but not all. Later on, another part of a text could be given with fewer divisions, thereby requiring the learners to rely more and more on themselves. Various permutations can be envisaged.

Once the sense groups are in place, the next process is to decide what sort of word or words are posing problems and what they might mean. These learners must learn to recognise verbs, nouns, adjectives and so on, both by their position and form. Discussion must be allowed to generate rules: e.g.,"when I see the termination -ness, this is probably the noun formed from the adjectival root; when I see a succession of adjectives followed by a noun, I can translate it by taking the noun first, then stringing the adjectives together from back to front". Having done this, it should be possible to understand.

31 If not, then a third step is to be undertaken. "How can I decompose the unknown word(s) in my sense group?" "Are there any prefixes, suffixes, which when stripped away from the word will give me the root?" If so, then this may give the meaning of the unknown word.

If this fails, my learners ask themselves the following question. "Does the word look like a French word?" If so, then the risk of substituting the French equivalent in its place is probably worth taking, despite the danger of "faux amis".

If this doesn't work, then the dictionary must be consulted, or the intuitive decision is to be taken to consider the word as relatively unimportant.

Obviously, space does not allow me to detail all the exercise types developed for these learners, but all are derived from the main principles I have described. However, I insist on the need to draw threads together, to make parallels between occurrences in different texts, since it is difficult for the learners to do this themselves, even though I ask my 
students as homework to do precisely this for two or three sentences from the forthcoming text they will read. This is the recycling, the spiralling I mentioned earlier, which finds its echo in the "unit coherence" that Hutchinson and Waters (1978: 113) describe. And so that all possible sources of comprehension are exploited, my group and I frequently go to their labs for hands-on experience with their equipment and computer programmes. In this respect, the fact that the lessons are held in the company's premises are a great boon.

The present situation is that we are, as already mentioned, at our third course together. Just how much progress has been made is difficult to say and evaluating it is entirely another debate. However, they did request more of the same punishment; moreover, they leave the class with a smile on their faces, which, according to Earl Stevick (1976) probably means that learning has taken place. A recent development has been to ask the learners to look briefly at a portion of unknown text, then to follow it in real time as I translate it orally for them without stopping. Any occurrences which have posed a problem of comprehension are then fluopenned and discussed together, first without me, then with. Another development which it has taken time to achieve for various reasons is the notion of the self-help comprehension group. Since the factory is large, break and meal times are different and the five ladies work in three different labs., it is difficult for them to ask each other for help viva voce. But since every department has its fax, the possibility exists for them to send each other textual queries that a) are concise and precise, unlike phone calls, and b) do not need to be dealt with in real time, again unlike phone calls. To date, two such self-help queries have been made, which is not many, but is a start.

Finally, what are these learners' limits? Clearly, they will never be very proficient readers of a wide range of genres because they lack the motivation to do so. After all, they were given a friendly push to start lessons in the first place. Moreover, they may have a an L2 reading threshold beyond which they may never pass owing to plateauing out of their knowledge of English. Yet with their detailed notes, they do possess the subskill knowledge to be able to handle most of the texts they are likely to come across professionally, even if their reading will always be a fairly slow, ponderous process.

\section{BIBLIOGRAPHY}

Allwright, R.L. 1981. “What do we want teaching materials for?”. ELT Journal 36/1, 5-18.

Anderson R.C. and P.D. Pearson. 1984. "A schema-theoretic view of basic processes in reading comprehension”. In Pearson, P.D., R. Barr, M.L. Kamil and P. Mosenthal (eds.), Handbook of Reading Research. New York: Longman.

Baten L. and A.-M. Cornu. 1985. "Reading strategies for LSP texts". In Perrin, M. (ed.), Pratiques d'aujourd'hui et besoins de demain, Proceedings of the 4th European Symposium on LSP. Bordeaux : Université Bordeaux 2. 
Dechet A. 1993. "Formation en anglais de spécialité dans les départements informatiques des IUT : choix des matériaux linguistiques et didactisation". ASp 1, 139-187.

Entreprises et Carrières 278. 1995. "Spécial Langues".

Fincher-Kiefer R. et al. 1988. "On the role of prior knowledge and task demands in the processing of text". Journal of Memory and Language 27.

Hutchinson T. and A. Waters. 1987. English for Specific Purposes: A learning-centred approach. Cambridge: Cambridge University Press.

Mémet M. 1994. Anglais de spécialité dans le domaine du génie électrique : "Aspects sociolinguistiques et applications didactiques résultant du traitement informatique des données". Thèse de doctorat, Université Bordeaux 2.

Nyman S. 1994. "Operating instructions: Directive text type under examination”. In Brekke, M. et al. (eds.), Applications and Implications of Current LSP Research, Proceedings of the 9th European Symposium on LSP. Bergen: Fagbokforlaget.

O'Neill R. 1982. "Why use textbooks?". ELT Journal 36/2.

Opitz K. 1985. “Evitable logomachy, or when LSP turns into fad”. In Perrin, M. (ed.), Pratiques d'aujourd'hui et besoins de demain, Proceedings of the 4th European Symposium on LSP. Bordeaux : Université Bordeaux 2.

Perrin M. 1990. “The necessary didactisation of authentic documents". Paper given at the 7th European Symposium on LSP, Budapest 1989, printed in Actes du Colloque GERAS. Bordeaux : Université Bordeaux 2.

Rivers W. 1994. "Efficient communication or just muddling through". In Brekke, M. et al. (eds.), Applications and Implications of Current LSP Research, Proceedings of the 9th European Symposium on LSP. Bergen: Fagbokforlaget.

Skulstad A.S. 1994. "The value of genre-centred approaches in ESP teaching”. In Brekke, M. et al. (eds.), Applications and Implications of Current LSP Research, Proceedings of the 9th European Symposium on LSP. Bergen: Fagbokforlaget, 780-788.

Stevick E. 1976. Memory, Meaning and Method. Rowley: Newbury House.

Swan M. 1985. “A critical look at the communicative approach (2)”. ELT Journal 39/2.

Symons S. and M. Pressley. 1993. "Prior knowledge affects text search success and extraction of information". Reading Research Quarterly 28/3.

\section{APPENDIXES}

\section{An approach to reduce the number of skin samples in testing the transdermal permeation of drugs}

Although glyceryl trinitrate (GT) is a drug that easily permeates through skin, the variations in its transepidermal fluxes were high. The arithmetic mean of the GT flux ( $\mathrm{n}=$ 31 skin samples from different individuals) was $16.5 \mu \mathrm{g} \mathrm{cm}-2 \mathrm{~h}-1$ with a standard deviation of $42 \%$. The extreme values were 4.1 and $36.9 \mu \mathrm{g} \mathrm{cm}-2 \mathrm{~h}-1$, i.e. they differed by a factor of 9 . Wide variations were also found for ephedrine, frusemide, caffeine, ethacrynic and benzoic acids and especially trospium chloride. All these fluxes were determined in an in vitro permeation model at $32^{\circ} \mathrm{C}$ using human epidermis. With the aim of 
standardising epidermal preparations on their permeability, the extent to which the in vitro GT fluxes through a human epidermal preparation correlate with those of other compounds was evaluated. The resulting standardisation procedure consisted of two interactive parts: (i) the correlation of the flux of a test substance with that of GT using epidermal samples from three donors and estimating the minimal, mean and maximum flux of the test compound and (ii) quantitation of the transepidermal permeation of the test compound with those standardised epidermal preparations by calculating the GT standard coefficient defined by the slope of the line derived from the relation between GT flux units and the corresponding flux from the test compound.

A: Although glyceryl trinitrate (GT) is a drug that easily permeates through skin, the variations in its transepidermal fluxes were high.

B: The arithmetic mean of the GT flux ( $\mathrm{n}=31$ skin samples from different individuals) was $16.5 \mu \mathrm{g} \mathrm{cm}-2 \mathrm{~h}-1$ with a standard deviation of $42 \%$.

C: The extreme values were 4.1 and $36.9 \mu \mathrm{g} \mathrm{cm}-2 \mathrm{~h}-1$, i.e. they differed by a factor of 9.

D: Wide variations were also found for ephedrine, frusemide, caffeine, ethacrynic and benzoic acids and especially trospium chloride.

E: All these fluxes were determined in an in vitro permeation model at $32^{\circ} \mathrm{C}$ using human epidermis.

F: With the aim of standardising epidermal preparations on their permeability, the extent to which the in vitro GT fluxes through a human epidermal preparation correlate with those of other compounds was evaluated.

G: The resulting standardisation procedure consisted of two interactive parts : (i) the correlation of the flux of a test substance with that of GT using epidermal samples from three donors and estimating the minimal, mean and maximum flux of the test compound and (ii) quantitation of the transepidermal permeation of the test compound with those standardised epidermal preparations by calculating the GT standard coefficient defined by the slope of the line derived from the relation between GT flux units and the corresponding flux from the test compound.

\section{NOTES}

1. See the weekly Entreprises et Carrières 278, which contains a survey of the present requirements of large companies in France. Of 50 questionnaires completed and returned, 82\% of companies stated that the main aim of their language training courses was specialisation in the firm's technical area.

2. For a discussion of this point, see Skulstad (1994).

3. Nyman (1994) describes how a frequency search in his corpus of nine full manuals of biomedical and telecommunications equipment showed that active verb forms comprised $26 \%$ of all finite verbs. Whereas passives comprised $33 \%$ of the finite verbs, imperatives represented $29 \%$. 


\section{ABSTRACTS}

This article describes an in-service course for teaching linguistically naïve laboratory technicians required by their employer to improve their understanding of complex scientific discourse. The aim involved apparent contradictions and difficulties in that this type of understanding calls for high-level cognitive and reading skills, whereas the professional group concerned did not possess this pre-existing linguistic knowledge on which a communicative learning approach might be expected to be constructed. Discussion centres on this divergence and on the didactic strategies used to go some way to closing this apparently unbridgeable gap.

Cet article décrit un stage de formation continue destiné à des techniciennes de laboratoire, pour qui une formation de compréhension écrite en anglais scientifique avait été requise par leur employeur. Les objectifs impliquaient des contradictions et des difficultés apparentes, dans la mesure où ce type de compréhension fait appel à des compétences cognitives et à des stratégies de lecture de haut niveau, alors que ce groupe professionnel ne possédait déjà pas les connaissances linguistiques sur lesquelles une approche communicative de l'apprentissage pourrait normalement être construite. L'auteur traite de cette divergence et des stratégies didactiques employées pour essayer de pallier ces lacunes apparemment très difficiles à combler.

\section{INDEX}

Mots-clés: approche didactique, discours scientifique, exigence professionnelle, lecteur de faible niveau

Keywords: didactic approach, low level reader, professional requirement, scientific discourse

\section{AUTHOR}

\section{RAY COOKE}

Ray Cooke teaches at Université Bordeaux 2. ray.cooke@u-bordeaux2.fr 